\title{
STUDYING THE INFLUENCE OF LOW-FREQUENCY AXIAL FLUCTUATIONS DURING SURFACE TREATMENT OF METALS
}

\author{
1,2Nikita BOGATOV, ' Veniamin BOLDYREV, ${ }^{2}$ Anastasiya SAVINA, ${ }^{2}$ Aleksandr ZOTKIN, \\ ${ }^{1}$ Anastasiya RAZVODOVA \\ 1Bauman Moscow State Technical University, Moscow, Russia, nikitabogatov@list.ru \\ ${ }^{2}$ D. Mendeleev University of Chemical Technology of Russia, Moscow, Russia, nikitabogatov@list.ru
}

https://doi.org/10.37904/metal.2020.3542

\begin{abstract}
Currently, it is known that infrasonic axial fluctuations affect various properties of metals. We conducted experimental studies to study the resistance of metals to corrosion in the field of infrasonic axial impacts. The subject of the study was the change in the properties of the surface of metals. It is established that when exposed to low frequency axial fluctuations in the range of 2-60 Hz occur changes in the processes of surface treatment of metals. Experimentally, optimal frequencies were found at which the effect of low frequency fluctuations becomes max. At the same time, each system under study has its own optimal experimentally detected frequency. Absorption spectroscopy is used to obtain results for the next systems: $\mathrm{HCl}-\mathrm{H}_{2} \mathrm{O}_{2}-\mathrm{Cu}$; $\mathrm{FeCl}_{3}-\mathrm{Cu} ; \mathrm{KI}-\mathrm{I}_{2}-\mathrm{Cu} ; \mathrm{HCl}-\mathrm{H}_{2} \mathrm{O}_{2}-\mathrm{Al} ; \mathrm{KI}-\mathrm{I}_{2}-\mathrm{Fe}$.

The use of the experimentally developed method of low frequency axial action allows increasing the speed of metal surface treatment up to 5 times. The study of the interaction of metals with electrolyte solutions in the field of low frequency fluctuations allows us to create new measures of protection against corrosion, as well as to develop new technological processes and solutions for surface treatment of metals and alloys for further implementation in the production process.
\end{abstract}

Keywords: Low frequency acoustic effects, processing of metals, kinetics, sonochemical processes, optimal frequencies

\section{EXPERIMENTAL PART}

The main direction of research is to use low frequency vibrations to affect the surface of metals. The most promising processes are surface treatment of such structural materials as alloys and semiconductors. The prospect of using the results obtained is application in the processes of metal surface treatment: polishing, milling and etching.

To conduct experiments, an Electromechanical installation was created, which is an oscillating system (oscillatory circuit) [1-7], consisting of an oscillating mass, elastic and dissipative elements. The characteristics of the experimental installation are shown in Table 1.

Table 1 Characteristics of the experimental installation

\begin{tabular}{|c|c|c|c|c|}
\hline Parameters & $\begin{array}{c}\text { Specific power } \\
\left(\mathbf{W} / \mathbf{c m}^{2}\right)\end{array}$ & Amplification & $\begin{array}{c}\text { The frequency } \\
\text { range }(\mathbf{H z})\end{array}$ & $\begin{array}{c}\text { Resonance frequency } \\
(\mathbf{H z})\end{array}$ \\
\hline Values & $3-7$ & $7-10$ & $1-100$ & 42.8 \\
\hline
\end{tabular}

We used etching solutions taken from everyday practice. To detect changes in the studied systems, the method of absorption spectroscopy of aqueous solutions was used. The optical density of aqueous solutions of the studied compounds was measured before and after exposure to low-frequency vibrations of the infrasound and the beginning of the sound ranges $(0-100 \mathrm{~Hz})$. We used a PE-5400V spectrophotometer with 
a measurement range from 335 to $1100 \mathrm{~nm}$. The qualification of the substances taken for the experiment is as follows: hydrochloric acid $-\mathrm{p}=1.19 \mathrm{~g} / \mathrm{cm}^{3}$; hydrogen peroxide-up to $30 \%$; iron chloride solution $-\mathrm{C}=400-600$ $\mathrm{g} / \mathrm{l}, \mathrm{p}_{\min }=1.3 \mathrm{~g} / \mathrm{cm}^{3} ; \mathrm{Ki}-\mathrm{I}_{2}$ solution prepared according to the standard method. In the case of copper, printed circuit boards with various carriers were used as objects: getinax GF-135 and foiled glass-fiber composite SF1-35. The sample for conducting experiments in the case of iron was the metal of the "Armco" brand. Aluminum was used as a foil used in the manufacture of capacitors.

\section{MEASUREMENT RESULT}

We have found that vibrations of the infrasound and the beginning of the sound (up to $100 \mathrm{~Hz}$ ) significantly affect the kinetics of metal surface treatment processes. When conducting systematic research, it was found that low frequency vibrations could cause acceleration of metal surface treatment processes from 2 to 5 times.

One of the results of the presented work is the proof of the existence of a dependence of the metal etching speed on the frequency of the affected vibrations. It was found that for all the studied systems, there is an optimal frequency of exposure, at which the etching rate becomes maximum. It was found that the influence of low frequency vibrations begins at a specific power of at least $3 \mathrm{~W} / \mathrm{cm}^{2}$. At lower power, low frequency axial vibrations only affect the electrolyte. This was taken into account when determining the effect of the topochemical process. And this is shown in (Figure 1).

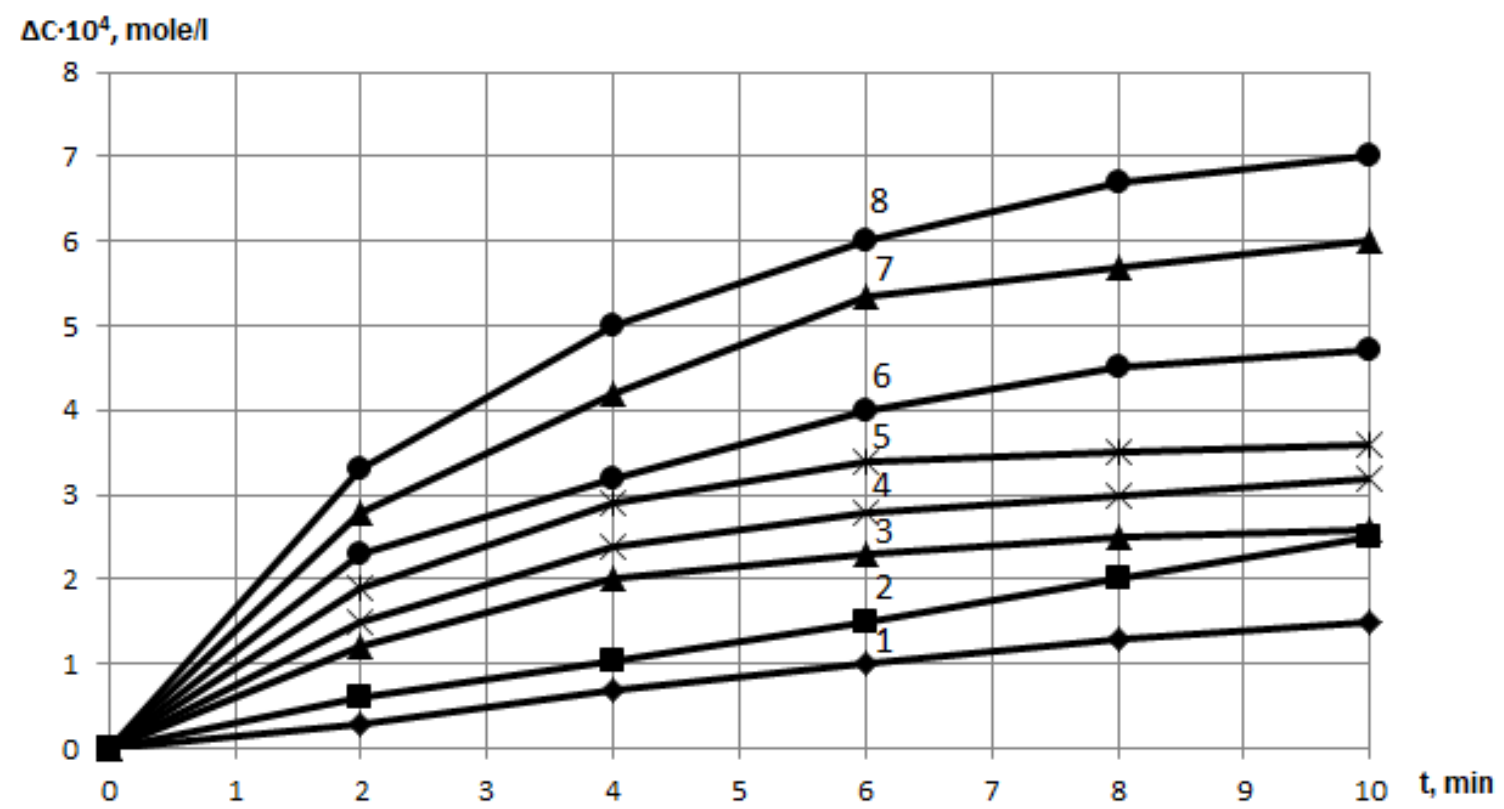

Figure 1 The etching rate of copper printed circuit boards with $\mathrm{KI}_{-} \mathrm{I}_{2}$ solution in the infrasonic range with a frequency of $15 \mathrm{~Hz}$ and various specific radiation powers: 1 - control solution of the etchant in the absence of metal; 2 - control solution containing copper, but not exposed to vibration; 3-8 - solutions under the influence of vibrations with different specific powers $\left(3-3.5 \mathrm{~W} / \mathrm{cm}^{2} ; 4-4.4 \mathrm{~W} / \mathrm{cm}^{2} ; 5-5.25 \mathrm{~W} / \mathrm{cm}^{2} ; 6-6.125 \mathrm{~W} / \mathrm{cm}^{2} ; 7\right.$ - $\left.7 \mathrm{~W} / \mathrm{cm} 2 ; 8-7.9 \mathrm{~W} / \mathrm{cm}^{2}\right)$

For (Figure 2) experimental data are presented for copper and iron when etched with a $\mathrm{KI}-\mathrm{I}_{2}$ solution at the same specific power. Thus, the change in the optical density of solutions without external influence is 4 times less than when using low-frequency axial vibrations.

Low frequency vibrations of the same power lead to different results depending on the metal. This may be because of low-frequency vibrations act not only on metals, but also on the products of etching on the surface of metals. This is due to the selection of the frequency and power of exposure shown in (Table 2) when using various etching solutions for surface treatment of each metal under study. 


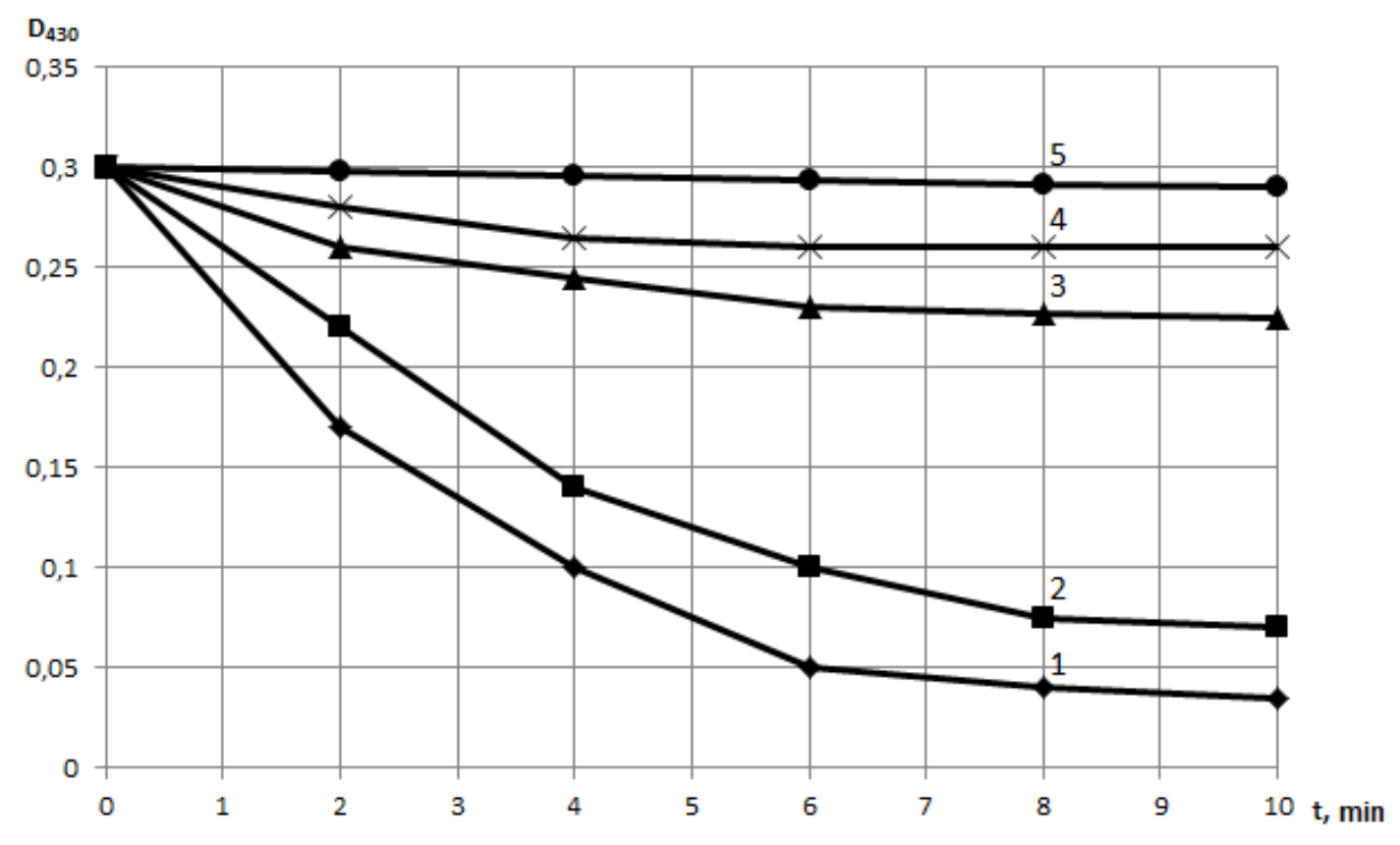

Figure 2 The rate of etching of copper $(2,4)$ and iron $(3,5)$ with a $\mathrm{KI}_{-} \mathrm{I}_{2}$ solution in the infrasonic range with a frequency of $15 \mathrm{~Hz}$ and a specific power of $7 \mathrm{~W} / \mathrm{cm}^{2}: 1$ - a control solution exposed to vibrations, but without metal; $\mathbf{4 , 5}$ - solutions with metal, but without the action of vibrations.

Table 2 Recommendations for the use of low-frequency vibrations to optimize the surface treatment of metals

\begin{tabular}{|c|c|c|c|c|}
\hline System & $\begin{array}{l}\text { Concentration of } \\
\text { components }(\mathrm{g} / \mathrm{l})\end{array}$ & $\begin{array}{c}\text { Optimal frequency } \\
(\mathrm{Hz})\end{array}$ & $\begin{array}{c}\text { Specific power } \\
\left(W / \mathrm{cm}^{2}\right)\end{array}$ & Area of use \\
\hline \multicolumn{5}{|c|}{ Etching of copper } \\
\hline $\mathrm{H}_{2} \mathrm{O}_{2}$ & 150 & $40 \pm 1$ & 5 & Etching of copper \\
\hline $\mathrm{HCl}: \mathrm{H}_{2} \mathrm{O}_{2}$ & $1: 1$ & $40-45$ & $3-5$ & $\begin{array}{l}\text { Etching of printed circuit } \\
\text { boards }\end{array}$ \\
\hline $\mathrm{HCl}: \mathrm{H}_{2} \mathrm{O}_{2}$ & $1: 2$ & $50-60$ & $3-5$ & $\begin{array}{l}\text { Etching of printed circuit } \\
\text { boards }\end{array}$ \\
\hline $\mathrm{FeCl}_{3}$ & $400-600$ & 50 & $3-5$ & $\begin{array}{l}\text { Etching of printed circuit } \\
\text { boardsm }\end{array}$ \\
\hline $\mathrm{KI}$ & $150-250$ & \multirow{2}{*}{30} & $5-7$ & \multirow{2}{*}{$\begin{array}{l}\text { Photochemical milling and } \\
\text { polishing }\end{array}$} \\
\hline $\mathrm{I}_{2}$ & $300-600$ & & $3-7$ & \\
\hline \multicolumn{5}{|c|}{ The etching of iron } \\
\hline $\mathrm{KI}$ & $120-180$ & \multirow[b]{2}{*}{40} & $5-7$ & \multirow{2}{*}{$\begin{array}{l}\text { Etching, corrosion } \\
\text { resistance testing of } \\
\text { coatings }\end{array}$} \\
\hline $\mathrm{I}_{2}$ & $350-500$ & & $3-7$ & \\
\hline $\mathrm{HCl}: \mathrm{H}_{2} \mathrm{O}_{2}$ & $2: 1$ & 55 & $3-5$ & $\begin{array}{l}\text { Etching, milling and } \\
\text { polishing }\end{array}$ \\
\hline \multicolumn{5}{|c|}{ Etching of aluminium } \\
\hline $\mathrm{HCl}: \mathrm{H}_{2} \mathrm{O}_{2}$ & $2: 1$ & $35 \pm 1$ & 5 & $\begin{array}{l}\text { Increasing the specific } \\
\text { capacity of capacitor } \\
\text { elements }\end{array}$ \\
\hline
\end{tabular}




\section{DISCUSSION OF RESULTS}

The use of low-frequency axial vibrations creates favorable opportunities for studying a number of physical and chemical interactions, such as diffusion, sorption, hydration, formation and destruction of surface compounds in topochemical reactions [8-12]. This was not known before, since the energy equivalent of vibrations of the infrasound and the beginning of the sound ranges is quite small [13-16]. The influence is manifested in changes in the conditions of physical and chemical interactions and allows us to study the features of the mechanism of ongoing reactions. The obtained research results are important both for understanding etching processes and for the problem of metal corrosion resistance. Analyzing the result obtained, we can conclude that the frequency of the applied vibrations is a characteristic parameter of corrosion failure.

This conclusion can be applied in the following areas:

1) development of structures and their operation taking into account the results obtained. It makes sense to exclude or minimize the possibility of dangerous frequencies that contribute to the occurrence of corrosion damage.

2) creating technologies and installations where low-frequency vibrations can play an important role in metal surface treatment.

3) the use of etchants that show little activity with conventional technology, but become very active if etching is performed using low-frequency axial influences.

The discovered effect of increasing the speed of chemical interactions in the field of low frequency axial vibrations has not only practical, but also important theoretical significance.

\section{CONCLUSION}

The applied value of this work is to develop recommendations for the intensification of technological processes, primarily the use of vibration and infrasound for etching, milling and polishing the surface of metals, alloys, semiconductors and other materials during homogenization, as well as for shifting the chemical kinetic equilibrium in one or another direction of the reversible process.

Theoretical analysis of the results obtained allowed us to determine the main features of the action of lowfrequency vibrations on processes in liquid media. Prior to the present research, the principal differences between the effect of low-frequency vibrations on topochemical reactions on the surface of metals and alloys and the action of higher-energy waves were not clear. As a result of the research, a method for studying heterogeneous processes in the field of low-frequency impacts was created.

\section{REFERENCES}

[1] FADEEV G.N., BOLDYREV V.S., SINKEVICH V.V. Sonochemical transformations of chelate and clathrate structures in a low-frequency acoustic field. Doklady Physical Chemistry, 2015. vol. 462, no. 2, pp. 119-123.

[2] FADEEV G.N., BOLDYREV V.S., AVERINA YU.M., BOGATOV N.A. Metal surface treatment in a low-frequency exposure field. Tsvetnye Metally, 2019, no. 10, pp. 73-77.

[3] FADEEV G.N., BOLDYREV V.S., BOGATOV N.A., NIKOLAEV A.L. Inhibition of oxidated reducing reactions in the field of low frequency impacts. Doklady Physical Chemistry, 2019, vol. 487, no. 1, pp. 91-93.

[4] KOVALEV A.A., KUZNETSOV N.N. Cavitation fracture of the typical materials used in hydraulic machines and units. Russian Metallurgy (metally), 2017, no. 13, pp. 1202-1206.

[5] MARGULIS M.A., MARGULIS I.M. Mechanism of sonochemical reactions and sonoluminescence. High Energy Chemistry, 2004, vol. 38, no. 5, pp. 285-294.

[6] MARGULIS M.A., MARGULIS I.M. Dependence of the rate of formation of nitrate ions in water on the intensity and frequency of ultrasound waves. Russian Journal of Physical Chemistry A, 2009, vol. 83, № 13, pp. 22332237. 
[7] MARGULIS M.A., MARGULIS I.M. On the conditions of the transition of sonochemical reactions into the kinetic region. Russian Journal of Physical Chemistry A, 2005, vol. 79, no. 11, pp. 1848-1853.

[8] ERSHOV Y.A., KHACHATURYAN M.A., SLONSKAYA T.K. Kinetic model of the enzyme catalysis of redox reactions. Russian Journal of Physical Chemistry A, 2019, vol. 93, no. 2, pp. 218-221.

[9] MIKHEEV Y.A., ERSHOV Y.A. Proof of the absence of trans-cis photoisomerization of methyl orange rydimers in an aqueous medium and inclusion complexes. Russian Journal of Physical Chemistry A, 2019, vol. 93, no. 11, pp. 2314-2322.

[10] MIKHEEV Y.A., ERSHOV Y.A. Photochemical reactions of aminoazobenzene in solutions, according to ultrafast vis spectroscopy data. Russian Journal of Physical Chemistry A, 2019, vol. 93, no. 6, pp. 1195-1203.

[11] GORSHKOVA V.M. Impact of low-frequency ultrasound on biological tissue. Herald of the Bauman Moscow State Technical University, Series Natural Sciences, 2015, no. 6, pp. 63-67.

[12] GORSHKOVA V.M., DVULICHANSKAYA N.N. The low-frequency ultrasound influence on lidocain and glycosaminoglycans. Herald of the Bauman Moscow State Technical University, Series Natural Sciences, 2017, no. 1, pp. 103-111.

[13] LIU Y., YU W. Effect of ultrasound on dissolution of Al in Sn. Ultrasonics Sonochemistry, 2019, vol. 50, pp. 67-73.

[14] WANG M., ZHOU Y. Numerical investigation of the inertial cavitation threshold by dual-frequency excitation in the fluid and tissue. Ultrasonics Sonochemistry, 2018, vol. 42, pp. 327-338.

[15] LEE H.B., CHOI P.K. Water-molecular emission from cavitation bubbles affected by electric fields. Ultrasonics Sonochemistry, 2018, vol. 42, pp. 551-555.

[16] THIEMANN A., CAIROS C., METTIN R., HOLSTEYNS F. Sonoluminescence and dynamics of cavitation bubbles populations in sulfuric acid. Ultrasonics Sonochemistry, 2017, vol. 34, pp. 663-676. 